\title{
UPAYA MENINGKATKAN PEMBELAJARAN LOMPAT TINGGI METODE BERMAIN DILINGKUNGAN SEKOLAH PADA SISWA KELAS VI SD NEGERI 165718 KOTA TEBING TINGGI
}

\author{
Tiurmaida* \\ Surel: tiurmaidaspd28@gmail.com
}

\begin{abstract}
The purpose of applying the method of playing methods in the School environment is that students are actively involved in learning activities and encourage students to be more creative, fostering confidence in learning. The method used in this study is Classroom Action Research (CAR). This research was conducted at 165718 Public Elementary School in Tebing Tinggi City, with the research subjects being Class VI students totaling 37 students. The average student learning outcomes in cycle I is 7.80 and cycle II is 8 . This is reinforced again by observing students who have significantly increased student activity and student responses to the application of playing methods in the School environment with 1 cycle presentation $64.86 \%$ and cycle 2 $92.43 \%$.
\end{abstract}

Keywords: Learning, High Jump, School Environment

\begin{abstract}
ABSTRAK
Tujuan dari penerapan model metode bermain di lingkungan Sekolah adalah siswa terlibat aktif dalam kegiatan pembelajaran dan mendorong siswa agar lebih kreatif, menumbuhkan kepercayaan diri dalam belajar. Metode yang digunakan dalam penelitian ini adalah Penelitian Tindakan Kelas (PTK). Penelitian ini dilakukan di SD Negeri 165718 Kota Tebing Tinggi, dengan subyek penelitian adalah siswa Kelas VI yang berjumlah 37 siswa. Rata-rata hasil belajar siswa siklus I sebesar 7,80 dan siklus II sebesar 8. Hal ini diperkuat lagi dengan obeservasi siswa yang mengalami peningkatan keaktifan siswa secara signifikans dan respon siswa terhadap penerapan metode bermain di lingkungan Sekolah dengan presentasi siklus 164,86\% dan siklus $292,43 \%$.
\end{abstract}

Kata Kunci: Pembelajaran, Lompat Tinggi, Di Lingkungan Sekolah

\section{PENDAHULUAN}

Pendidikan
merupakan suatu proses seseorang
sebagai individu maupun anggota
masyarakat yang dilakukan secara
sadar dan sistematik melalui berbagai
kegiatan dalam rangka memperoleh
kemampuan dan keterampilan
jasmani, pertumbuhan, kecerdasan,
dan pembentukan watak. Objek dasar
teori Pendidikan Jasmani Olahraga
dan Kesehatan ialah gerak
manusia.Tujuan Pendidikan Jasmani

Olahraga dan Kesehatan di sekolah dasar terfokus pada pengembangan aspek nilai-nilai dalam pertumbuhan, perkembangan, dan sikap perilaku anak didik, serta peningkatann keterampilan gerak dasar manusia. Pendidikan jasmani merupakan usaha pendidikan dengan menggunakan aktivitas otot-otot besar hingga pendidikan yang berlangsung tidak terhambat oleh gangguan-gangguan kesehatan dan pertumbuhan badan. 
Sebagaia bagaian integral dari proses pendidikan keseluruhan, pendidikan jasmani merupan usaha yang bertujuan untuk mengembangkan kawasan organik, neuromuskular, intelektual dan social (H. Abdul Kadir Ateng, 1992:4). Penyelenggaraan pendidikan jasmani di sekolah dasar selama ini berorentasi pada pengajaran cabang - cabang olahraga yang sifatnya mengarah pada penguasaan teknik secara detail dari cabang olahraga yang diajarkan. Tuntutan yang demikian selalu mempengaruhi persepsi dan pola pikir guru pendidikan jasmani. Kenyataan ini dapat di lihat dilapangan. Dari hasil pengamatan dapat dikatakan bahwa penyelenggaraan pendidikan jasmani di sekolah dasar belum dikelola sebagaimana mestinya sesuai dengan pertumbuhan dan perkembangan peserta didik, baik dari segi kognitif. Afektif, motorik, maupun fisik. Tujuan pembelajaran Penjasorkes akan terwujud apabila pelajaran pendidikan jasmani diajarkan dengan menggunakan metode, model dan pendekatan yang sesuai dengan kondisi sekolah yang bersangkutan. Akan tetapi yang menjadi masalah adalah keterbatasan sarana dan prasarana pembelajaran yang dimiliki sekolah yang masih belum terpenuhi, baik secara kuantitas maupun kualitasnya, sehingga akan menjadi kendala terhadap keberhasilan proses pembelajaran penjasorkes itu sendiri. Oleh karena itu pengembangan model pembelajaran dapat dijadikan alternatif dalam mengoptimalkan pembelajaran Penjasorkes di sekolah dan mutlak diperlukan untuk membuat proses pembelajaran dapat dilaksakan sebaik-baiknya. Pembelajaran lompat tinggi merupakan media untuk mendorong pertumbuhan fisik, perkembangan psikis, keterampilan motorik dan penalaran, penghayatan nilai-nilai (sikap, mental, emosional, sportivitas dan spiritual), serta pembiasaan pola hidup sehat yang bermuara untuk merangsang pertumbuhan dan perkembangan kualitas fisik dan psikis yang seimbang, juga dapat berpengaruh pada prestasi di negeri ini. Sekolah SD Negeri 165718 Kota Tebing Tinggi, merupakan salah satu sekolah di Kota Tebing Tinggi yang mengajarkan lompat tinggi. Akan tetapi proses pembelajarannya belum dapat dilakukan secara maksimal karena Kelas VI belum dapat melewati mistar menggunakan gaya guling denagan baik. Dari jumlah seluruh siswa yaitu 37 siswa yang terdiri dari 17 laki-laki dan 20 perempuan, masih ada beberapa siswa yang belum berhasil dengan sempurna melakukan gerak dasar lompat tinggi gaya guling. Berdasarkan hasil tersebut dapat dikatakan bahwa pembelajaran Penjaskes pada materi lompat tinggi gaya guling belum maksimal. Kesulitan yang dialami siswa dalam melakukan lompat tinggi adalah saat melakukan gerak mengambil ancangancang melompat. Ragu dalam mengambil ancang-ancang membuat hasil langkahan kakiuntuk melewati mistar tidak dilakukan dengan 
maksimal. Langkahan kaki terlalu rapat antar kaki yang melangkah lebih dulu dengan mistar sehingga tersentuh mistar. Ada lagi yang telah melangkah dengan benar tapi saat kaki kedua melangkah badan tidak di angkat sehingga mengenai mistar dan jatuh. Beberapa siswa masih mengalami kesulitan perempuan dalam mencoba melewati mistar lompat tinggi. Oleh sebab itu, dalam upaya meningkatkan ketuntasan belajar, dapat peneliti melakukan metode yaitu melakukan pembelajaran lompat tinggi dengan meggunakan metode bermain di lingkuangan Sungai mempraktekan teknik lompat tinggi dari awal sampai akhir untuk meningkatkan keterampilan gerak dasar lompat tinggi. Atas latar belakang inilah, penulis tertarik untuk mengadakan penelitian tindakankelas (Classroom Action Research) dengan judul: Upaya meningkatkan pembelajaran lompat tinggi dengan menggunakan metode bermain dilingkungan Sekolah pada siswa Kelas VI SD Negeri 165718 Kota Tebing Tinggi Tahun Pelajaran 2015/2016.

latar belakang di atas dapat diidentifikasi permasalahan: Apakah pembelajaran lompat tinggi dengan menggunakan metode bermain di lingkungan Sekolah pada Kelas VI SD Negeri 165718 dapat meningkatkan hasil belajar siswa?

Penelitian ini bertujuan untuk meningkatkan pembelajaran lompat tinggi dengan mengunakan metode bermain di lingkungan Sekolah pada Kelas VI SD Negeri 165718 Kota Tebing Tinggi Tahun Pelajaran 2015/2016.

Hasil belajar siswa akan meningkat, siswa semangat dalam mengikuti kegiatan pembelajaran karena model pembelajaran yang baru, menyenangan dan bervariasi, sehingga siswa termotivasi mengikuti pembelajaran terebut.

\section{Bagi Guru}

Guru dapat meningkatkan kemampuan dalam menciptakan model pembelajaran yang kreatif dan inovatif guna meningkatkan mutu pendidikan.

\section{Bagi Sekolah}

Hasil penelitian ini sebagai masukan guna peningkatan pembelajaran pendidikan jasmani dan peningkatan kualitas sekolah.

Sebagaimana diuraikan pada permasalahan di atas, maka pemecahan masalah yang dilakukan adalah sebagai berikut, menggunakan metode bermain di lingkungan Sekolah pada Kelas VI SD Negeri 165718 Kota Tebing Tinggi Tahun Pelajaran 2015/2016.

Subjek penelitian adalah peneliti sebagai observer dan guru mata pelajaran penjasorkes Kelas VI sedangkan objeknya adalah siswa SD Negeri 165718 Kota Tebing Tinggi Kelas VI yang berjumlah 37 orang 
Tiurmaida: Upaya Meningkatkan Pembelajaran....

siswa dengan komposisi putra 17 orang dan putri 20 orang.

Objek Penelitian adalah Siswa

SD Negeri 165718 Kota Tebing Tinggi Kelas VI.

Penelitian ini akan dilaksanakan pada semester 2 Kelas VI SD Negeri 165718 Kota Tebing Tinggi tahun ajaran 2015/2016 yaitu pada bulan April sampai Juni tahun 2016.

Penelitian ini dilaksanakan di lingkungan Sekolah dan lapangan SD Negeri 165718 Kota Tebing Tinggi yang merupakan tempat kerja peneliti sebagai pendidik / guru Penjaskes.

Tes adalah instrumen atau alat yang digunakan untuk memperoleh informasi tentang individu atau objek. (Ismaryati 2008 : 1). Metode tes ini digunakan untuk mengambil data tentang hasil belajar siswa setelah mengalami pembelajaran (tes praktek lompat tinggi dengan meneggunakan metode bermain dilingkungan Sekolah).

Dokumentasi adalah sekumpulan catatan, penyimpanan dan desiminasi dari catatan informasi dalam sistem terintegrasi untuk penggunaan yang efisien dan mudah diterima. Dokumentasi merupakan persiapan dan catatan komunikasi, mendorong untuk membuktikan suatu informasi dan kejadian (Muslihatun, Mufdlilah dan Setiyawati, 2009:3). Metode dokumentasi diperlukan untuk mendapatkan data berupa nama siswa, jumlah siswa Kelas VI serta foto dan video kegiatan pembelajan lompat tingi dengan menggunakan metode bermain dilingkungan Sekolah di SD Negeri 165718 Kota Tebing Tinggi Tahun Pelajaran 2015/2016.

Analisis Data

Analisa data adalah kegiatan untuk memaparkan data, sehingga dapat diperoleh suatu kebenaran atau ketidak benaran dari suatu hipotesis. Batasan ini diungkapkan bahwa analisis data adalah sebagai proses yang merinci usaha secara formal untuk menemukan tema dan merumuskan ide seperti yang disarankan oleh data sebagai usaha untuk memberikan bantuan pada tema dan ide (Riko wijaya, Juni 2015).

Prosedur

Penelitian

digunakan dalam penelitian ini adalah metode Penelitian Tindakan Kelas (PTK), yaitu suatu pencermatan terhadap kegiatan berupa sebuah tindakan, yang sengaja dimunculkan dan terjadi dalam sebuah kelas secara bersama (Aqib, 2006:12). Menurut Arikunto (2006:3) Tindakan diberikan oleh guru atau dengan arahan dari guru yang dilakukan oleh siswa. Jika kita lihat dari pengertian tersebut, penelitian tindakan kelas sangat baik untuk kita terapkan dalam dunia pendidikan. Ini terlihat dari pencermatan kegiatan belajar yang dilakukan oleh siswa yang tidak lepas pengawasan seorang guru. Adapun tujuan dari penelitian tindakan kelas adalah untuk memperbaiki dan meningkatkan praktik pembelajaran di kelas secara berkesinambungan. 


\section{HASIL DAN PEMBAHASAN}

Dalam penelitian ini peneliti menggunakan subjek penelitian satu kelas yaitu Kelas VI, sesuai dengan prinsip kerja penelitian tindakan kelas (PTK). Dalam proses pembelajaran di kelas, subjek peneliti juga diberikan tes pada setiap siklusnya, dengan tujuan untuk mengetahui peningkatan hasil belajar siswa setelah mengikuti pembelajaran dengan model pembelajaran lompat tinggi dengan metode bermain dilingkungan Sekolah pada mata pelajaran Penjasorkes pokok bahasan lompat tinggi, hasil belajar siswa meliputi tiga aspek penilaian yaitu aspek psikomotor, afektif dan kognitif.

Hasil belajar pada aspek psikomotorik siklus 1 rata-rata nilai 8,03 dan siklus 2 rata-rata nilai 8,41 . Aspek Afektif siklus 1 rata-rata nilai 7,84 dan siklus 2 rata-rata nilai 8,24. Aspek Kognitif siklus 1 rata-rata nilai 7,54 dan siklus 2 rata-rata nilai 7,95. Sedangkan rata-rata seluruh aspek pada siklus ke 1 adalah 7,80 dan pada siklus 2 adalah 8,20. Dari hasil analisis hasil belajar siklus 1 dan siklus 2 terdapat selisih perbedaan rata-rata kelas, dimana ini terlihat peningkatan hasil belajar siswa antara siklus 1 dan siklus 2, sehingga kita dapat melihat selisih nilai rata-rata siklus 1 dan siklus 2 yaitu 0,4 Melihat selisih dari rata-rata kelas berarti dengan penerapan lompat tinggi dengan metode bermain dilingkungan Sekolah hasil belajar siswa cukup bagus.
Sesuai hasil penelitian angket di atas, dapat disimpulkan bahwa pembelajaran pembelajaran lompat tinggi dengan penerapan metode bermain di lingkungan Sekolah ternyata mendapat tanggapan/respon yang sangat baik. Hal ini ditunjukkan semua siswa yang merespon baik semua pertanyaan yang diberikan, yaitu sebesar $92,43 \%$ atau dapat dikatakan bahwa pembelajaran lompat tinggi sudah berhasil sesuai dengan tujuan yang ingin dicapai meskipun masih ada beberapa anak yang belum maksimal. Berdasarkan analisis proses pembelajaran dan hasil pembelajaran siswa pada siklus 2 cukup memuaskan, walaupun ada beberapa siswa yang nilainya masih kurang memuaskan, akan tetapi, berdasarkan kemampuan dan hasil tersebut secara umum sudah baik. Dari pelaksanaan tindakan yang ditempuh, diperoleh hasil yang cukup memuaskan, meskipun belum maksimal. Oleh karena itu, perlu diadakan tindakan selanjutnya, namun keterbatasan peneliti dan waktu yang diperlukan, maka peneliti menghentikan kegiatan penelitian ini dengan harapan temuan-temuan yang diperoleh dapat dujadikan acuan untuk penelitian lebih lanjut. Hal ini menunjukan bahwa pembelajaran lompat tinggi dengan menggunakan metode bermain dilingkungan Sekolah, proses dan hasil pembelajarannya mengalami peningkatan. 
Tiurmaida: Upaya Meningkatkan Pembelajaran....

Berdasarkan deskripsi, analisis, dan refleksi setiap siklus pada penelitian yang telah dilaksanakan, ternyata pembelajaran lompat tinggi dengan menggunakan metode bermain di lingkungan Sekolah dapat meningkatkan pemahaman ketrampilan siswa dalam melakukan lompat tinggi. Jadi secara empirik hipotesis yang diajukan peneliti dalam penelitian ini terbukti diterima. Hal ini terbukti dari beberapa temuan yang yang peneliti temukan dari tes awal, siklus 1 dan siklus 2 selama penelitian berlangsung. Temuan-temuan itu akan dijelaskan sebagai berikut :

Pada awal-awal pelaksanaan masih banyak siswa yang kelihatan kebingungan dan kurang mengerti. Tetapi setelah kegiatan berlangsung, terlihat semua siswa bersemangat dan merasa senang. Sedangkan pada saat guru melakukan tes, terlihat siswa masih kebingungan dengan gerakan yang akan dilakukan. Hal ini dikarenakan sebelumnya guru tidak mencontohkan dan memberitahukan mengenai langkah-langkah gerakan melakukan lompat tinggi seperti sikap awal melakukan, tolakan, badan saat di udara dan pendaratan sehingga masih banyak siswa yang pada saat melakukan gerakan masih diluar tehnik yang benar. Adapun dari hasil tes siklus 1 yang dilakukan, niai ratarata kelasnya hanya 7,80 terlihat dari hasil tes tersebut skor yang di dapat siswa relatif cukup. Pada siklus 1 ditemukan adanya perubahan pada saat mengikuti kegiatan inti pembelajaran dengan menggunakan metode bermain di lingkungan Sekolah siswa lumayan bagus. Selain itu pada saat guru melakukan evaluasi dengan melakukan lompat tinggi gaya sebagian siswa sudah sedikit memahami dan mengerti, dan skor yang diperoleh siswa pun mengalami perubahan. Adapun hasil tes yang dilakukan pada sklus 2 ini, sudah mengalami peningkatan, terlihat dari hasil tes siklus 2 tersebut skor yang diperoleh siswa sudah mengalami peningkatan dari data awal ke siklus 1, walaupun untuk rata-rata skor kelas masih di bawah KKM yang telah ditentukan yaitu 8,20 .

Temuan yang peneliti temukan pada siklus 2 yaitu siswa sudah menunjukan peningkatan yang sangat baik mulai dari awal pembelajaran sampai akhir pembelajaran. Ketika siswa melakukan latihan tugas gerak yang guru perintahkan, siswa sudah tidak merasa takut dan mampu meminimalisisr kesulitan gerak yang mereka alami serta mampu melakukan tugas gerak dengan optimal. Selain itu, pada saat evaluasi yang dilakukan guru dengan melakukan tes lompat tinggi terlihat hampir keseluruhan siswa sudah memahami dan mengerti langkahlangkah dan tehnik-tehnik melakukan gerakan yang baik dan benar, walaupun masih ada beberapa siswa yang masih belum memahami. Namun demikian ketrampilan siswa dalam pembelajaran lompat tinggi pada siklus ke 2 ini cukup meningkat dari siklus sebelumnya, ini terihat dari 
skor siswa sudah tergolong baik, dan skor rata-rata yang didapatpun sudah melebihi KKM yang telah ditentukan oleh sekolah yaitu 75 .

\section{SIMPULAN}

Peningkatan hasil belajar
siswa dengan penerapan model
pembelajaran lompat tinggi dengan
mengunakan metode bermain di
lingkungan Sekolah pada Kelas VI
SD Negeri 165718 Kota Tebing Tinggi mengalami peningkatan yang baik. Hal ini dilihat dari persentase kriteria hasil belajar siswa pada setiap siklusnya. Siklus 1 rata-rata hasil belajar siswa untuk aspek kognitif, psikomotor dan afektif adalah 7,80 sedangkan siklus 2 rata-rata hasil belajar siswa untuk aspek kognitif, psikomotor dan afektif adalah 8,20. Keaktifan siswa mengalami peningkatan yang mendukung proses pembelajaran diikuti respon siswa terhadap pembelajaran terhadap penerapan model pembelajaran lompat tinggi dengan mengunakan metode bermain di lingkungan Sekolah respon siswa sangat baik untuk proses kegiatan belajar dengan menerapkan metode bermain di lingkungan Sekolah dengan prosentasi siklus ke 1 adalah 64,86\% dan siklus 2 adalah 92,43\% .

Bagi siswa yang masih belum mempunyai kepercayaan diri dalam proses pembelajaran, hendaknya siswa bekerjasama dalam belajar supaya ada peningkatan hasil belajar siswa. Guru hendaknya memperhatikan perkembangan pembelajaran siswa pada saat ini, sehingga inovasi pembelajaran dapat dilakukan dan proses pembelajaran tidak monoton.

\section{DAFTAR RUJUKAN}

Zainal, Aqib. 2009. Penelitian Tindakan Kelas untuk Guru. Bandung: CV. Yrama Widya.

Suharsimi, Arikunto dkk. 2008. Penelitian Tindakan Kelas. Jakarta: Bumi Aksara.

Suharsimi, Arikunto. 2006. Prosedur Penelitian: suatu Pendekatan Praktik. Jakarta: Rineka Cipta.

Slameto. 2003. Belajar dan FaktorFaktor Yang Mempengaruhinya. Jakarta: PT Adi Mahasatya

Subagiyo. 2008. Perencanaan Pembelajaran Pendidikan

Jasmani. Jakarta, Universitas Terbuka.

Nana Syaodih, Sukmadinata. 2004.

Landasan Psikologi

Proses Pendidikan. Bandung: Rosdakarya.

Syafaruddin, dan Irwan Nasution. 2005. Manajemen

Pembelajaran. Jakarta: PT Ciputat Press. Tulus,

Tu'u. 2004. Peran Disiplin Pada Perilaku Dan Prestasi Siswa. Jakarta: PT.

Gramedia Widiasarana Indonesia (Grasindo) . Tudjai. 2000. Analisis Hasil Belajar 
Tiurmaida: Upaya Meningkatkan Pembelajaran....

Kemampuan Kependidikan,

dalam Jurnal Teknologi

Pendidikan Vol. 2 No. 1.

Mulyasa. 2008. Menjadi Guru

Profesional Menciptakan

Pembelajaran Kreatif dan Menyenangkan. Bandung : PT

Remaja Rosdakarya.

Rochiati, Wiriaatmadja. 2009.

Metode Penelitian Tindakan

Kelas. Bandung: Rosdakarya. 